\title{
The Effect of Bank Competition on Cost of Credit: Empirical Evidence from the Visegrad Countries
}

\author{
Ashiqur Rahman \\ Tomas Bata University in Zlin, Czech Republic \\ Email: rahman@utb.cz
}

\begin{abstract}
The effects of bank competition on the cost of credit are a much-debated topic in Small and Medium enterprises financing. In this paper, we would like to examine the relationship between the cost of credit and interbank-competition in the context of Visegrad countries - the Czech Republic, Poland, Hungary, and the Slovak Republic. The dataset of this paper comes from two different sources, the firm level data provided by the latest version of the Business Environment and Enterprise Performance Survey that was conducted by the European Bank for Reconstruction and Development and the World Bank during the period from 2012 to 2014, and the country level bank competition measures are collected from the Beck et al. (2000) Global Financial Database, updated in 2017. We have examined bank competition with four measures, including structural bank concentration measure and three non-structural (Lerner Index, $\mathrm{H}$ Statistics, and Boone Index) measures. We find evidence that bank competition has a positive effect on the cost of credit and hence, our results are in-line with prior literature on informationbased theories of bank competition. We have also assessed the firms in terms of their information opacity (micro, small, and medium), and we find that the cost of credit is higher for the information opaque firms. Thus, firm sizes have important implications for bank competition and cost of credit.
\end{abstract}

Keywords: Cost of credit, bank competition, SME, Visegrad countries

JEL Classification: G20, G21, G31, O16

\section{Introduction}

Financial constraints on small and medium enterprises (SMEs) are an ongoing topic in entrepreneurial finance. The limited access to bank finance for the SMEs has been an issue that is far from settled in both developed and developing countries. The role of banks in facilitating the credit services to the business sectors are extremely vital for the development of private business sectors and for the economic welfare of a country. The banking market structure is considered as one of the important elements that can have a significant effect on the access to finance for firms and to reduce financial constraints.

It is well documented in the prior literature that SMEs are facing difficulties in accessing bank loans due to information asymmetry. The reduction of information asymmetry can increase access to finance for SMEs, reduce loan interest rate, lower collateral requirements and overall facilitates the availability of finance (Berger and Udell, 2002; Beck et al., 2004; Godlewski and Weill, 2011). However, the influence of information asymmetry on reducing financial constraints can be affected by the nature of bank market structure, for example, competition and concentration in the market. 
The literature on competition based studies argued the effect of bank competition from two different perspectives. At one hand, the market power hypothesis suggests that the bank competition can increase access to finance, reduce interest rates and lower collateral requirements for SMEs (Besanko and Thakor, 1992; Leon, 2015; Hainz et al., 2013). The theory is based on the general economic assumption that the higher competition can lower the cost of credit and enables better access to finance. Therefore, the market power hypothesis considers interbank competition is preferable for the SMEs by which financial constraints can be alleviated. On the other hand, the information hypothesis suggests that banking competition can increase financial constraints for firms due to a high asymmetric information and agency costs. The information hypothesis argues that the higher competition reduces bank incentive to investment in relationship lending (Petersen and Rajan, 1995; Dell' Ariccia and Marquez, 2006) and hence higher financial constraints due to more asymmetric information between banks and borrowers. A few literatures discuss that a high competition reduces bank quality of loan screening process (Marquez, 2002) and reduces bank incentives in relationship-based lending technologies (Hauswald and Marquez, 2006). Overall, the information hypothesis argues that the intensive bank competition is not desirable for SMEs, as it increases financial constraints.

Regardless of the conflicting views on bank competition and financial constraints on SMEs, a great deal of empirical research tested bank market power and information hypothesis in different markets. Beck et al. (2004) find that banking concentration has a positive effect on financial constraints for SMEs, thus supporting market power hypothesis. On the other hand, assuming bank competition is opposite to concertation, Petersen and Rajan (1995) argue that bank concentration has a positive effect on access to finance for SMEs, hence lower credit restrictions.

While a number studies examined the effect of bank market power in relation to access to finance (Ryan et al., 2014; Leon, 2015; Alvarez and Bertin 2016; Love and Peria, 215), in this paper, we intend to follow a different path by examining the effect of bank market power on cost of credit for SMEs. By using the World Business Environment Survey (WBES), Beck et al. (2006) show that the high cost of credit is the first and foremost problems for SMEs that restrict the firms to access bank loans. Therefore, considering the importance of cost of credit in SME financing, the aim of this paper is to understand the relationship between bank market structure and its effect on pricing of loans.

The current research is based on the Visegrad countries (Czech Republic, Slovak Republic, Poland, and Hungary). We have selected the Visegrad group on purpose, because the Visegrad countries are strategically important for the European Union. On top of that, we can provide a cross-country evidence from the central European countries. This paper contributes to the existing literature on cost of credit and bank market competition in several ways. First, the competition measures of this paper are a combination of structural and non-structural measures. Second, the sample of firms are from the Visegrad countries and so far, this research is the first empirical evidence from the Visegrad group in relation to cost of credit and bank market structure. Third, we provide a new evidence based on firm information opacity and its impact on the cost of credit.

The rest of the paper is organized as follows. Section 2 discusses the current literature on market power and its implications on access to finance and cost of credit. Section 3 presents the data set and describes the variables and empirical methodology. Section 4 discusses the descriptive and estimation results. Section 5 concludes the paper. 


\section{Literature Review}

From a theoretical perspective, lending to SMEs requires to build-up a long-lasting relationship by which it is possible to acquire soft-information and to minimize information gap. The reduction of information asymmetry may positively affect access to finance for SMEs and hence minimal financial constraints. However, in a competitive market banks have less incentives to provide loans based on relationship banking. Because in a competitive environment a borrower can easily switch from one bank to another, hence the minimum value added to the bank from investment in relationship banking (Boot and Thakor, 2000). However, when a bank has market power it can try to develop a long-lasting relationship with the borrower by which a bank can extract exclusive private information from the borrowers (Petersen and Rajan, 1995). Information based theory by Petersen and Rajan (1995) suggests that a bank can give-up immediate rent or profit margin from borrowers when they have market power, but they can take the advantage later on when the bank will have superior authority over the borrowers. However, the situation is opposite for banks that are operating in a competitive market. They may ask for the same rate of interest and profit margin from the borrowers' due to competitive pressure. The authors proposed that the bank market power can increase the investment in relationship banking that simplifies information asymmetry and lessen financial constraints for SMEs. Malafronte et al. (2014) argue that banking competition gives the opportunity to the bank to develop a more private banking relationship with the borrower and invest more in relationship lending technologies, because by doing so a bank can create its superiority over other lenders by eliminating price competition.

The current research on bank market structure examined the effect of bank competition and concentration from different perspectives such as access to finance, cost of credit, collateral requirements, financial constraints, discouraged borrowers and so on. The studies related to access to finance and bank market power provide evidence that high bank concentration can increase financial constraints on SMEs, hence, higher competition is associated with better access to finance. In this regard, Beck et al. (2004) examined the effect of banking concentration and its effect on access to credit for developing countries, and find that banking concentration is associated with more financial constraints for SMEs. A study by Dong and Men (2014) provided evidence from a sample of SMEs in 119 emerging countries and find that banking concentration is associated with higher financial constraints and thus, they supported the view of market power hypothesis and suggested that in emerging markets high concentration is not desirable. Similarly, Love and Peria (2015) found that bank market power reduces access to credit for SMEs with respect to 53 developing countries. However, they argue that the negative effect of bank market power is reduced depending on the countries that are financially developed and well-structured credit market. Likewise, they find that availability of credit information sharing system can reduce the effect of bank market power.

The empirical research on bank competition based studies argue that the choice of competition measures can have a significant effect on the outcome of results and the interpretation of results can differ by the competition indicator (Carvo-Velverde et al., 2009b). Therefore, it is an important issue to select the competition measure that best explains the bank market structure of the country. However, the appropriate selection of competition measure is a debatable issue in bank finance research, because different countries have different banking systems and that can affect the results of any cross-country research. 
A few recent empirical research used structural and non-structural measures of competition by which they can enhance the validity and robustness of research. Leon (2015) examined credit constraints in 69 developing countries by including both structural and non-structural measures (Concentration ration, Lerner index, Boone and $\mathrm{H}$ statistic) of competition and the paper finds that bank competition can alleviate credit constraints for SMEs. The results show that the banks evaluate loan applications less strictly when competition is higher. On the other hand, countries with less bank competition face higher credit rationing due to high bank concentration. Claessens and Laeven (2005) used Panzar - Rosse H - statistic as a proxy for bank competition measure in their analysis of 16 countries and they find that bank competition has a positive effect on the growth of firms those are largely depended on bank finance and the result is true for countries those have high competition in the market. Hence, bank competition can facilitate access to finance and growth of firms. Ryan et al. (2014) provide more evidence on bank market power and financial constraints from a sample of 20 European countries and they find that the higher bank competition is associated with lower credit constraints on SMEs. To measure financial constraints, they have used the Fazzari et al. (1988) investment sensitive model and the Lerner index is used to capture the market power and it is found that in a competitive market SMEs are less sensitive to their investment policy. Carvo-Velverde et al. (2009) examined the effect of bank competition and access to finance through the availability of trade credit from a sample of Spanish SMEs, the authors find that in a competitive market SMEs have more access to trade finance and hence, supporting market power hypothesis. Moro et al., (2015) examining the relationship between bank competition and access to finance in the Italian market and find that bank competition is associated with higher credit for SMEs. Thus, they find that bank competition can minimize financial constraints on SMEs.

While a great deal of papers examined the issue of access to finance and bank competition, a few studies are done on how bank competition affect the pricing of loans. The preliminary research by Petersen and Rajan (1995) find that bank competition has a positive effect on the cost of credit and that means that higher the competition higher is the cost of credit. Fungacova et al. (2017) used a sample of firms from 20 European countries and they have used two-structural and two non-structural measures of competition. The results show that the bank competition has a positive effect on the cost of credit. The authors also examined the effect of competition on the cost of credit based on firm information opacity and they find that small and medium firms need to provide more interest rate on their borrowing than of the large firms. It is argued that small firms encounter the information problems more than the large firms and thus competition has a harsher effect on the firms those are depended on relationship based lending. Therefore, both above studies are supporting information hypothesis of bank competition. On the other hand, Hainz et al. (2013) find that bank competition can relax the lending terms by reducing collateral requirements and interest rates on loan contact. Hence, empirical studies on bank competition and its relationship with the cost of credit are mixed and that is why we have chosen to reexamine the issue in the context of Visegrad countries.

\section{Data, method and variables}

\subsection{Data}


This paper utilizes data from the Business Environment and Enterprise Performance Survey (BEEPS) that was conducted by the European Bank for Reconstruction and Development and the World Bank during the period of 2012 to 2014. The survey is performed to understand the overall business environment and the enterprises' performance related factors in 30 transition and emerging countries including European, Central Asian countries and Russia. The survey covered 1,374 firms in four examined countries - 254 from the Czech Republic, 310 from Hungary, 542 from Poland, and 268 from the Slovak Republic. According to the aim of the paper, the small and medium enterprises are defined, under the Convention of the Organization for Economic CoOperation and Development (OECD) and the guidelines are given in the survey, as enterprises with a maximum of 250 employees. Due to a large amount of missing data and after excluding the large firms from the sample size, the analysis involves 1,296 records about firms for descriptive statistics, and 230 firms have disclosed information about the cost of credit in the survey. Regardless, of the firm level data from the BEEPS survey, we have collected the country level competition measures data from the Beck et al. (2000), Global Financial Database, which is updated in 2017.

\subsection{Variables}

To examine the effect of bank competition on the cost of credit, we have collected the cost of credit information from the BEEPS survey question " $\mathrm{Q} 46$ - What is the annual nominal interest rate (in percent) of the most recent line of credit of loan". Cost of credit is our main dependent variable in the context of the research. A detailed list of variables is presented in Table 1.

In this paper, we have a few firm level control variables such as, Firm size (Size), Firm age (Age), Largest Owner (Largest Own), Borrower Experience (Experience), Audit (Audit), and Innovation (Innovation). Firm size (SIZE) is counted by number of full-time employees the firm employed during the BEEPS survey. We expect to find a negative relationship between firm size and cost of credit because larger firms may face less information opacity problem and can access loans with a lower interest rate (Hsiao and Chou, 2015; Neuberger and Rathke-Doppner (2015). After firm size, we control for firm age (Age), which is measured as the number of years the firm is in operation. We expect to find a negative relationship between firm size and cost credit, the fact is that the older firms may have a better business relationship with the banks and other external lenders due to their long existence in the market and hence they may access loans with better credit terms, such as lower interest rate (Bellucci et al., 2013). In this current paper, we also control for firm ownership structure and its effect on cost of credit. According to the agency theory, firms with more concentrated ownership and those owned and managed by the same person have minimum or, at times, zero agency costs (Jensen and Meckling 1976; Fama, Jensen 1983). Ang (1992) shows that firms with concentrated ownership tend to have a long-term orientations and strive for survival and reputation, hence less agency related conflicts. Therefore, we expect to find a negative relationship between ownership concentration and cost of credit. Because, less agency cost may reduce the credit risk of the firm and which may induce lenders to provide loans with lower price. Additionally, we control for borrower experience and its effect on the cost of credit. Borrower experience is the years of experience of the top manager within the current business or related businesses. Neuberger and Rathke-Doppner (2015), find that that the cost of credit is lower 
for an experienced borrower than of the younger borrower. Because, an experienced borrower can manage the business well than of the inexperienced borrower and hence, it signals lower credit risk of the firm. Thus, banks and other external lenders can provide loans with lower interest rates. On the other hand, Grunert and Norden (2012), argue that an experienced borrower can have more bargaining power with the creditors than of the inexperienced borrower and which may lead to lower cost of credit. Hence, we expect to find a negative relationship between cost of credit and borrower experience. Afterwards, we control for firm financial reporting status and its relationship with cost of credit. We measure financial reporting status of the firm with audit (Audit) report. Audit is a dummy variable that takes one if the firm financial statement is checked by external auditors and zero otherwise. It is widely discussed in prior literature that when a firm has its financial statement audited by external auditors, it can help to minimize information asymmetry between firms and the creditors and thus can receive loans with less credit restrictions (Nguyen and Wolfee, 2016; Leon, 2015). Therefore, we expect to find a negative relationship between audit report of the firm and cost of credit. Because lower information transparency may increase lenders confidence on the borrower and provide loans with lower cost of credit. Finally, we control for firm innovation activity and its impact on cost of credit. It is argued that innovative firms are more information opaque compared to the non-innovative firms. Thus, innovative firms face higher credit restrictions than of the non-innovative ones (Lee et al., 2015; Freel, 2007). Considering the above theoretical arguments surrounding the innovative SMEs, we expect to find a positive effect of bank competition on cost of credit.

Table 1: Definition and sources of variables

\begin{tabular}{|c|c|c|}
\hline Variable & Definition & Source \\
\hline Cost of credit & Annual interest rate on loan & BEEPS \\
\hline \multicolumn{3}{|c|}{ Firm-level control } \\
\hline Size & Size of the firm, measured as the number of full-time employees & BEEPS \\
\hline Age & Age of firm, measured as the number of years that the firm has been operating & BEEPS \\
\hline Largest. Own & Percentage ownership of the firm held by the largest shareholder & BEEPS \\
\hline Experience & Experience of top manager measure in years & BEEPS \\
\hline Audit & Equals 1 if the firm financial statement is checked by external auditors $(0,1)$ & BEEPS \\
\hline Innovation & Equals 1 if the firm has introduced any new products within the last three years & BEEPS \\
\hline \multicolumn{3}{|c|}{ Competition measures } \\
\hline H-stat. & A measure of the degree of competition & Beck (2000) \\
\hline Lerner & A measure of market power in the banking market & Beck (2000) \\
\hline Boone & A measure of the degree of competition based on Profit -efficiency in the banking market & Beck (2000) \\
\hline CR5 & The asset share of the five largest banks in total banking system assets & Beck (2000) \\
\hline
\end{tabular}

This table presents variable definitions and sources of the data set. BEEPS = Business Environment and Enterprise Performance Survey. 


\subsubsection{Competition Measures}

The purpose of this paper is to examine the effect bank competition on the cost of credit and hence, it is necessary to select appropriate measures of bank competition. The literature on competition based studies classified bank competition into two segments: structural indicators and non-structural indicators. With respect to structural indicators, the theory suggests that the excessive concentration in the banking sector can be considered an opposite to bank competition and in a concentrated market a bank can ask for higher loan rates from the borrower by which it can generate more profits than in a competitive market. The commonly used structural bank competition measure is concentration ratio, which is in inverse proxy of competition and is calculated by asset share of the largest five banks in the total banking system $(\mathrm{Cr})$. We intend to use concentration ratio as a measure of structural measure of bank competition.

Apart from the concentration ratio, we have employed three (Lerner index, $\mathrm{H}$ statistics, and Boone index) non-structural measures of bank competition in this paper. The Lerner index captures the market power of a bank and which is calculated by the difference between output prices and marginal costs of inputs. The prices are calculated as total bank revenue over assets, whereas marginal costs are obtained from an estimated translog cost function of three inputs (labor, physical capital and deposits; a detailed methodological explanation is cited in Love and Martinez Peria, 2015) with respect to output. The higher values of the Lerner index indicate less bank competition. That means that when a bank can set higher prices over the costs, it has more market power and that is why it can set higher prices over the costs. Because in a competitive market, it would be difficult for a bank to charge higher prices than the marginal costs.

In this paper, we also introduced Panzar-Rosse H statistics (Panzar-Rosse, 1987), which is also a commonly used coopetition measure in banking literature. The Panzar and Rosse (1987) model measure the elasticity of bank revenues to its input prices and it shows that under certain condition the prices of inputs vary depending on the degree of competition in the market. The H statistics value provides information about the degree of competition in a market and by which it is possible to understand the competitive nature of the banking industry in a market. When a market operates under a perfect competition, the H-statistic equals 1 . Whereas under a monopoly, an increase in input prices results in a rise in marginal costs, a fall in output, and a decline in revenues leading to an H-statistic less than or equal to 0 . And, H-statistic is between 0 and 1 , when the banking sectors operate under monopolistic competition.

Finally, the competition measures we introduced in this paper is the Boone index. Boone (2008) introduced a model based on the price elasticity of profits to marginal costs. To estimate the elasticity the log of profits (measured by return on assets) is regressed on the log of marginal costs. The estimated coefficient (computed from the first derivative of a trans-log cost function) is the elasticity. Hence, the more negative the Boone indicator, the higher the degree of competition is because the effect of reallocation is stronger. The basic intuition of the model is that only the efficient banks can earn a higher level of profits in terms of their costs. Additionally, the model explains that the propensity of earnings increases with the competitive nature of the market. That means that, as the market gets more competitive the efficient banks can generate more profits than of the inefficient banks. The Boone indicator is intensively used in the banking literature because it has some advantages over other competition measures (Delis, 2012; Love and Martinez Peria, 
2015; Leon, 2015). The Boone indicator captures the dynamics and non-price related factors in the market, however, the Boone index is calculated at a country level and it does not capture the regional differences within the country. Hence, the index may not be not well fitted when performing analysis on a large country. Since the regional differences in a banking environment may create differences in overall countrywide banking competition measures. To make the empirical results more understandable, in this paper we used the inverse of Boone index, that means that higher the values of Boone index higher is the competition.

\subsection{Methodology}

The aim of this paper is to examine the relationship between bank competition and the cost of credit in the context of the Visegrad group. The cost of credit is a continuous variable and as a result, we intend to use an OLS regression model that is the best fit for our purpose. The empirical model to be examined as follows:

$\mathrm{Y}_{\mathrm{fct}}($ cost of credit $)=\beta_{1}$ Firm level controls fct $+\beta_{2}$ Competition $_{\mathrm{ct}}+\varepsilon_{f c t}$

Where $\mathrm{Y}$ is the cost of credit, and fct represent firm (f), country (c), and time (t). In our baseline model, we have Firm level controls (size, age, ownership, etc.); Competition indicates one of our competition measures, and $\varepsilon_{i}$ Is the usual error term. In our model, the impact of bank competition is indicated by $\beta$. As already discussed elsewhere, the higher values of competition measures are associated with a lower level of competition ( $\mathrm{Cr}$ and Lerner) and higher values competition measures are associated with higher levels of competition (Boone index and the $\mathrm{H}$ statistics). That can also be said that three of our competition measures are an inverse proxy of bank market competition. Hence, if $\beta>0$ that means higher concentration is associated with higher cost of credit and if we find a $\beta<0$, that means higher concentration is associated with lower cost of credit.

\section{4. $\quad$ Results}

\subsection{Descriptive statistics}

In Table 2, we present the descriptive statistics of our full sample. The Table shows that the average cost of credit is about $8.15 \%$ of our sample. However, the maximum cost of credit is about $70 \%$ and which is tremendously high. This preliminary result may highlight that the SMEs sometimes need to pay an extremely high price for their loans, regardless of the nature of competition in the banking sector. Considering the firm level determinants of the cost of credit, we see that an average firm employs 33 employees and hence it could be said that most of the firms in our sample are in the range of small firms (10-49). If we consider the firm age, it is possible to see that the average maturity of the SMEs is about 18.5 years. However, the sample suggests that the firm age ranges from 1 to 81 years. That may highlight that our sample covers both mature and just newly established firms. As per the ownership structure of firms, we find that SMEs are highly concentrated with $77 \%$ of concentration, hence, that may reflect that SME owners are more likely to keep their control over the firm by holding a large share. In terms of borrower business experience, we can see that the mean experience of the borrower is about 21 years. Considering 
the borrower experience, we may find a negative association with the cost of credit, because an experienced borrower may have more bargaining power in comparison to the inexperienced borrower. The descriptive statistics suggest that about $34 \%$ of SMEs in our sample have their financial statement audited. The audited financial statement can have a significant impact in determining the cost of credit, since, it shows the quality of firm's financial information also reduces information asymmetry. With respect to innovation, we can see that about $31 \%$ of the SMEs have introduced new products within the last three years. The result may reflect that the SMEs in our sample countries are not actively participating in innovation activities.

With respect to the competition measures, we find that banking sector is highly concentrated in our sample with a five-bank concentration ratio of $68.42 \%(\mathrm{CR})$. On the other hand, we can see that the Lerner index was in between 0.13 to 0.40 during the survey period, and $\mathrm{H}$ statistics show that it ranges from 0.61 to 0.70 , whereas, Boone index was 0.01 to 0.16 .

\subsection{Empirical results}

In Table 3, we present the regression results for each of the competition measures and their relationship with the cost of credit. As already discussed, $\mathrm{Cr}$ and Lerner index indicate that higher values of competition measures are related to lower levels of competition and conversely, $\mathrm{H}$ statistics and Boone index (inverse values of Boone index are used in this paper) suggest that higher values of competition measures are associated with higher levels of competition in the market. In column 1, we see that the coefficients of $\mathrm{Cr}$ are negative, similarly, in column 2, the coefficients of Lerner index are also significant and negative. We find that the

Table 2: Descriptive statistics

\begin{tabular}{|l|l|l|l|l|l|}
\hline Variable & Obs. & Mean & Std. Dev & Min & Max \\
\hline Cost of credit & 230 & 8.15 & 7.27 & 0.00 & 70.00 \\
\hline Firm characteristics & & & & & \\
\hline Size & 1296 & 32.91 & 45.53 & 1.00 & 245.00 \\
\hline Age & 1292 & 18.34 & 8.87 & 1.00 & 81.00 \\
\hline Largest. Own & 1267 & 76.38 & 26.21 & 0.00 & 100.00 \\
\hline Experience & 1228 & 20.41 & 9.86 & 1.00 & 57.00 \\
\hline Audit & 1286 & 0.34 & 0.47 & 0.00 & 1.00 \\
\hline Innovation & 1295 & 0.31 & 0.46 & 0.00 & 1.00 \\
\hline Competition measures & & & & & 88.52 \\
\hline CR5 & 1296 & 68.42 & 13.41 & 53.66 & 0.40 \\
\hline Lerner & 1296 & 0.29 & 0.09 & 0.13 & 0.73 \\
\hline H-stat. & 1296 & 0.63 & 0.05 & 0.61 & 0.16 \\
\hline Boone & 1296 & 0.07 & 0.05 & 0.01 & . \\
\hline
\end{tabular}

Note: Firm level variables are authors calculation based on the BEEPS survey and competition measures are obtained from the Beck et al. (2000) GFDD database.

Finally, the results for Boone index shows a positive significant result with the cost of credit (column 4). Hence, if we consider the results for the first two competition measures, it suggests that the higher concentration is negatively related to cost of credit and from the results we may say 
that the higher level of concentration can help the firms to get loans with lower interest rates. However, the cost of credit is higher when market competition is excessive. The competition results are in line with the information hypothesis, where we argue that the competition does have a positive impact on the cost of credit, due to less benefit of banks in investing relationship lending. Hence, lack of information availability increases the cost of credit for borrowers. The results for Boone index suggests that the high competition in the market can increase the cost of credit and thus our results for all competition measures are in line with the information hypothesis, apart from the $\mathrm{H}$ statistics. Therefore, we may say that market competition is not helpful to reduce the cost of credit, rather a concentration structure of the banking system in the Visegrad group is more suitable to reduce the cost of credit for the borrowers. Our results suggest that the structural and non-structural competition measures have the similar implications on the cost of credit and the selection of competition measures does not distort the interpretation of our results. The results of this paper are in line with recent literature on bank competition and cost of credit such as Fungacova et al. (2017) and Petersen and Rajan (1995) who have also found that high bank competition increases the cost of credit and which is mainly driven by the information problems associated with SMEs.

With respect to the firm level controls, we find that firm size has a negative impact on the cost of credit and the results are stable for all competition measures. Thus, the result suggests that larger firms may have easy access to finance with a lower cost of credit due to their more bargaining power than of the smaller firms or the large firms are more transparent and information asymmetry may not have a detrimental effect on the large firms' credit availability. In terms of firm age, the results show that the cost of credit is higher for the larger firms than of the smaller firms. The results are opposite to our expectation. We expected a negative association with firm age and cost of credit due to their mature business status and that might give the aged and older firms a better credit contract from the bank with a lower cost of credit. However, this result could be the fact that the banks charge more interest rates on their loans from the mature and older firms because they are able to give more interest on their borrowing than of the younger and new born firms. We have found a positive relationship between ownership structure of firms and cost of credit but the results are not statistically significant across our four competition measures. However, we did not find any significant effect of borrower experience, audit, and innovation activities of firms on the cost of credit. The coefficient for $\mathrm{H}$ statistics are negative but not statistically significant (column 3 ). 
Table 3: Main estimation results

\begin{tabular}{|c|c|c|c|c|}
\hline & \multicolumn{4}{|c|}{ Dependent variable $=$ Cost of credit } \\
\hline & CR5 & Lerner & H-Stat. & Boone \\
\hline \multirow[t]{2}{*}{ Competition } & $-0.123 * * *$ & $-22.056 * * *$ & -12.637 & $39.55 * * *$ \\
\hline & $(-0.039)$ & $(5.310)$ & $(9.680)$ & $(10.058)$ \\
\hline \multirow[t]{2}{*}{ Size } & $-0.0363 * * *$ & $-0.037 * * *$ & $-0.0341 * * *$ & $-0.038 * * *$ \\
\hline & $(0.011)$ & $(0.010)$ & $(0.011)$ & $(0.01)$ \\
\hline \multirow[t]{2}{*}{ Age } & $0.209 * * *$ & $0.245 * * *$ & $0.246 * * *$ & $0.25 * * *$ \\
\hline & $(0.011)$ & $(0.056)$ & $(0.058)$ & $(0.057)$ \\
\hline \multirow[t]{2}{*}{ Largest_own } & 0.006 & 0.010 & 0.000 & 0.009 \\
\hline & $(0.018)$ & $(0.017)$ & $(0.018)$ & $(0.017)$ \\
\hline \multirow[t]{2}{*}{ Experience } & -0.031 & -0.063 & -0.052 & -0.069 \\
\hline & $(0.048)$ & $(0.047)$ & $(0.049)$ & $(0.0477)$ \\
\hline \multirow[t]{2}{*}{ Audit } & -0.388 & -0.357 & -1.091 & -0.383 \\
\hline & (1.028) & $(0.997)$ & $(1.0156)$ & $(1.002)$ \\
\hline \multirow[t]{2}{*}{ Innovation } & $(-0.573)$ & 0.130 & -0.559 & -0.15 \\
\hline & $(0.948)$ & $(0.941)$ & $(0.968)$ & $(0.938)$ \\
\hline \multirow[t]{2}{*}{ Constant } & $15.143 * * *$ & $12.830 * * *$ & $14.714 * *$ & $3.66 * * *$ \\
\hline & (3.33) & 2.405 & 6.494 & $(2.03)$ \\
\hline R_Squared & 0.37 & 0.41 & 0.33 & 0.4 \\
\hline
\end{tabular}

Source: Authors estimation. Dependent variable: cost of credit. Statistical significance at the 10\%, 5\% and 1\% level indicated by $*$, ** and $* * *$, respectively. Standard errors are in parentheses.

\subsection{Empirical results by firm information opacity}

The literature on information based study suggests that the smaller firms experience the negative effect of competition more than the larger firms. The intuition is that the small firms are more information opaque and hence they need to develop a long-lasting relationship with the banks and by which it is possible to alleviate information gap between banks and borrowers. However, when there is an intensive competition in the market it reduces the bank's incentives to invest in relationship lending because in a competitive environment a borrower can easily switch from one to another bank. Hence, the switching behavior of borrowers is reducing the bank benefits of investment in relationship lending (Petesen and Rajan, 1995). Based on the above argument, we intend to examine whether market competition does affect the cost of credit of the SMEs due to their information opacity. To test the firm level information opacity, we have segmented the firms according to their sizes (micro, small and medium) and depending on the competition in the market we may expect to find a greater positive relationship between the cost of credit and micro firms and a lesser impact on the smaller and medium firms. The empirical results are presented in Table 4 and 5. 
The results (Table 4) suggest that the effect of bank competition measures on the cost of credit differs according to the firm sizes. We find that the concentration ratio $(\mathrm{Cr})$ has a positive effect on the cost of credit for micro firms, while a negative effect on the small and medium firms. It could be the fact the in a concentrated market micro firms have less alternative options for loans and more importantly micro firms may not be able to get loans with lower interest rates not only because of information opacity but also due to their limited capacity in providing collateral or business guarantee (Duarte et al., 2016; Jimenez et al., 2006; Rahman et al., 2017a; Rahman et al., 2017b). The results for Lerner index suggest that in a concentrated market micro firms provide a lower cost of credit than of the small or medium firms. Hence the results do support the information hypothesis that the micro and opaque firms face the negative effect of bank competition more than the medium firms.

The coefficients for the Boone index (Table 5) is positive and statistically significant for the micro and small firms and we did not find any effect of Boone index on the medium firms. These results also support the information hypothesis and we can say that micro and small firms are facing higher loan rates in a competitive market than in a concentrated market. Therefore, information asymmetry can be a significant factor in determining the cost of credit and which is also depended on the nature of the market structure in the Visegrad countries. The results for $\mathrm{H}$ statistics is not statistically significant for the micro and medium firms but we have found a negative effect on the medium firms. The results of the $\mathrm{H}$ statistics were not significant in our main estimation but we did find a negative association with the cost of credit, that may imply that when information gap is lower it can lower the cost of credit for the SMEs and higher competition can increase the cost of credit.

Table 4: Estimation by firm opacity (1/2)

\begin{tabular}{|l|c|c|c|c|c|c|c|}
\hline Variable & \multicolumn{7}{|c|}{ Cependent variable = Cost of credit } \\
\hline & \multicolumn{3}{|c|}{ CR5 } & & \multicolumn{3}{c|}{ Lerner } \\
\hline & Micro & Small & Medium & & Micro & Small & Medium \\
\hline Competition & $0.038^{*}$ & $-0.101^{* * *}$ & $-0.283^{* * *}$ & & $-31.706^{* * *}$ & $-28.816^{* * *}$ & -9.481 \\
\hline & $(0.094)$ & $(0.04)$ & $(0.115)$ & & $(12.575)$ & $(6.297)$ & $(16.247)$ \\
\hline Size & 0.317 & -0.030 & $-0.066^{* * *}$ & & 0.367 & -0.045 & $-0.058^{* * *}$ \\
\hline & $(0.241)$ & $(0.050)$ & $(0.025)$ & & $(0.588)$ & $(0.047)$ & $(0.028)$ \\
\hline Age & 0.195 & 0.041 & $0.170^{* *}$ & & 0.319 & 0.0326 & $0.237 * * *$ \\
\hline & $(0.626)$ & $(0.077)$ & $(0.092)$ & & $(0.224)$ & $(0.072)$ & $(0.093)$ \\
\hline Largest_own & -0.063 & 0.012 & 0.025 & & -0.014 & 0.018 & 0.026 \\
\hline & $(0.051)$ & $(0.019)$ & $(0.003)$ & & $(0.049)$ & $(0.018)$ & $(0.048)$ \\
\hline Experience & -0.204 & -0.061 & 0.045 & & -0.189 & -0.065 & 0.081 \\
\hline & $(0.155)$ & $(0.052)$ & $(0.110)$ & & $(0.146)$ & $(0.048)$ & $(0.114)$ \\
\hline Audit & 4.642 & $-2.852^{* * *}$ & 0.107 & & 4.550 & $-3.531^{* * *}$ & 0.881 \\
\hline & $(2.786)$ & $(0.989)$ & $(2.935)$ & & $(2.619)$ & $(0.910)$ & $(3.479)$ \\
\hline Innovation & 2.32 & -0.211 & 3.290 & & 2.673 & -0.287 & -1.584 \\
\hline & $(2.436)$ & $(0.978)$ & $(2.986)$ & & $(2.311)$ & $(0.919)$ & $(2.951)$ \\
\hline & & & & & & & \\
\hline Constant & 6.82 & $16.596^{* * *}$ & $26.958^{* * *}$ & & $13.760^{* * *}$ & $19.463 * * *$ & 7.366 \\
\hline & $(8.489)$ & $(3.741)$ & $(10.653)$ & & $(6.777)$ & $(3.098)$ & $(7.444)$ \\
\hline R_Squared & 0.33 & 0.43 & 0.56 & & 0.44 & 0.53 & 0.47 \\
\hline
\end{tabular}


Source: Authors estimation. Dependent variable: cost of credit. Statistical significance at the $10 \%, 5 \%$ and $1 \%$ level indicated by $*, * *$ and $* * *$, respectively. Standard errors are in parentheses.

Table 5: Estimation by firm opacity $(2 / 2)$

\begin{tabular}{|c|c|c|c|c|c|c|}
\hline \multirow[t]{3}{*}{ Variable } & \multicolumn{6}{|c|}{ Dependent variable $=$ Cost of credit } \\
\hline & \multicolumn{3}{|c|}{ H-Stat } & \multicolumn{3}{|c|}{ Boone } \\
\hline & Micro & Small & Medium & Micro & Small & Medium \\
\hline \multirow[t]{2}{*}{ Competition } & 14.30463 & -10.538 & $-55.040 *$ & $39.252 *$ & $54.118 * * *$ & 33.73597 \\
\hline & $(23.644)$ & 9.713 & $(29.388)$ & $(22.95)$ & $(12.18)$ & $(29.24)$ \\
\hline \multirow[t]{2}{*}{ Size } & 0.284 & -0.019 & $-0.060 * * *$ & 0.220 & -0.050 & $-0.064 * * *$ \\
\hline & $(0.622)$ & 0.051 & $(0.026)$ & $(0.60)$ & $(0.05)$ & $(0.03)$ \\
\hline \multirow[t]{2}{*}{ Age } & 0.307 & 0.078 & $0.246 * * *$ & 0.306 & 0.037 & $0.243 * * *$ \\
\hline & $(0.236)$ & 0.077 & $(0.09)$ & $(0.23)$ & $(0.07)$ & $(0.09)$ \\
\hline \multirow[t]{2}{*}{ Largest_own } & -0.058 & 0.009 & 0.016 & -0.034 & 0.021 & 0.029 \\
\hline & $(0.622)$ & 0.019 & $(0.05)$ & $(0.049)$ & $(0.018)$ & $(0.047)$ \\
\hline \multirow[t]{2}{*}{ Experience } & -0.200 & -0.084 & 0.038 & -0.191 & -0.072 & 0.060 \\
\hline & $(0.154)$ & 0.052 & $(0.112)$ & $(0.150)$ & $(0.048)$ & $(0.114)$ \\
\hline \multirow[t]{2}{*}{ Audit } & 4.62 & $-3.298 * * *$ & 1.439 & $4.821 * *$ & $-3.491 * * *$ & 1.520 \\
\hline & $(2.772)$ & 0.991 & $(3.247)$ & $(2.696)$ & $(0.914)$ & $(3.446)$ \\
\hline \multirow[t]{2}{*}{ Innovation } & 2.240 & -0.316 & -3.664 & 2.566 & -0.528 & -1.472 \\
\hline & $(2.429)$ & 1.004 & $(2.624)$ & $(2.380)$ & $(0.926)$ & $(2.709)$ \\
\hline \multirow[t]{2}{*}{ Constant } & -0.453 & $16.034 * * *$ & $41.624 * * *$ & 4.224 & $6.972 * * *$ & 2.468 \\
\hline & $(16.880)$ & $(6.658)$ & $(20.497)$ & $(7.221)$ & $(2.225)$ & $(6.292)$ \\
\hline R_Squared & 0.33 & 0.38 & 0.53 & 0.39 & 0.52 & 0.49 \\
\hline
\end{tabular}

Source: Authors estimation. Dependent variable: cost of credit. Statistical significance at the $10 \%, 5 \%$ and $1 \%$ level indicated by $*$, ** and ***, respectively. Standard errors are in parentheses.

\section{Conclusion}

The bank competition and its implications on financial constraints has been an on-going topic in economic literature. The theory of market power hypothesis suggests that bank competition should relax financial constraints by reducing the interest rate on loans, collateral requirements and enhances access to credit to firms. In contrast, the information hypothesis predicts that bank competition can have a significant negative effect on access to credit and can increase financial constraints due to high information asymmetry between firms and banks. Because, in a competitive market, banks are reluctant to invest in relationship lending technologies and hence increases financial constraints due to a high asymmetric information.

In this paper, we examined the effect of bank competition on the cost of credit by using a sample of SMEs from Visegrad countries (Czech Republic, Slovak Republic, Hungary and Poland). To encounter the information problems associated with bank competition and cost of credit, we have used four proxies of bank competition: concentration ratio, Lerner index, Panzar-Rosse $\mathrm{H}$ statistics and Boone index. The results of our paper suggest that the bank competition is associated with 
higher cost of credit and thus, our results are aligned with existing literature on information hypothesis of bank competition that high bank competition increases financial constraints on SMEs. Therefore, we reject the view that the bank competition can relax the lending terms and enhances access to finance.

We have also segmented the firms in terms of their sizes as per the intuition that micro and small firms may face higher credit restrictions than of the medium or large firms due to information opacity and bank competition. Our results do support that micro and small firms need to provide higher loan rates than of the medium firms. Hence, we find evidence that the effect of bank competition in increasing cost of credit is larger on the firms those are financially opaque and need to access loans via relationship lending.

The policy makers may implement policies by which excessive bank competition can be alleviated from the market and that can lower the lending rates in the Visegrad countries. It could also be helpful to remove barriers by which SMEs can access loans with lower restrictions. The effect of bank competition may be lessened by improving the financial literacy of the borrowers by which they can prepare better loan proposals and more importantly the borrowers can keep their business accounting records more efficiently. The future research can be done to check how country specific factors affect the cost of credit on borrowing. Additionally, whether banks are charging higher prices not only for high competition in the market but also is there any factors that force them to charge high prices needs to be investigated.

\section{Acknowledgement:}

Ashiqur Rahman is grateful to the Internal Grant Agency of FaME TBU No. IGA/FaME/2017/010: Financial Constraints on Economic Activities, for financial support to carry out this research. 


\section{References}

Alvarez, R., \& Berten, M. J. (2016). Banking competition and firm-level financial constraints in Latin America. Emerging Markets Review, 28, 89-104.

Ang, J. (1992). On the theory of finance for privately held firms. Journal of Entrepreneurial Finance, 1(3), 185-203.

Beck, T., Demirguc-Kunt, A., \& Levine, R. (2000). A new database on financial development and structure. World Bank Economic Review, 14, 597-605.

Beck, T., Demirguc-Kunt, A., \& Maksomovic, V. (2004). Bank competition and access to finance as a growth constraint. Journal of Banking and Finance, 30(11), 2931-2943.

Beck, T., Demirguc-Kunt, A., Laeven, L., \& Maksimovic, V. (2006). The determinants of financing obstacles, Journal of International Money and Finance 25, 932-952. https://doi.org/10.1016/j.jimonfin.2006.07.005

Belluchi, A., Borisov, A., \& Zazzaro, A. (2010). Does gender matter in bank-firm relationships? Evidence from small business lending, Journal of Banking and Finance 34, 2968-2984. http://dx.doi.org/10.1016/j.jbankfin.2010.07.008

Berger, A. N., \& Udell, G. F. (2002). Small business credit availability and relationship lending: the importance of bank organisational structure, The Economic Journal, 112(477), 32-53. DOI: $10.1111 / 1468-0297.00682$

Besanko, D., \& Thakor, A.V. (1992). Banking deregulation: allocational consequences of relaxing entry barriers. Journal of Banking and Finance, 16(5), 909-932.

Boone, J. (2008). A new way to measure competition. The Economic Journal, 118(531), 12451261.

Boot, A., \& Thakor, A. (2000). Can relationship banking survive competition? The Journal of Finance, 55(2), 679-713.

Carbo-Velverde, S., Humphery, D., Maudos, J., \& Molyneus, P. (2009a). Cross-country comparisons of competition and pricing power in banking. Journal of International Money and Finance, 28(1), 115-134.

Carbo-Velverde, S., Rodriguez-Fernandez, F., \& Udell, G.F. (2009b). Bank Market power and SME financing constraints. Review of Finance, 13(2), 309-340.

Claessens, S., \& Laeven, L. (2005). Financial dependence, banking sector competition, and economic growth. Journal of the European Economic Association, 3(1). 179-207.

Delis, M. D. (2012). Bank competition financial reform and institutions: the importance of being developed. Journal of Development Economics, 97(2), 450-465. 
Dell' Ariccia, G., \& Marquez, R. (2006), Lending booms and lending standards. Journal of Finance, 61(5), 2511-2546.

Dong, Y. \& Men, C. (2014). SME financing in emerging markets: firm characteristics, banking structure and institutions. Emerging Markets Finance and Trade, 50(1), pp. 120-149.

Duarte, F. D., Gama, A. P. M., \& Esparanca, J. S. (2016). The role of collateral in the credit acquisition process: evidence from SME lending, Journal of Business Finance and Accounting 43(5), 693-728. doi: 10.1111/jbfa.12207

Fama, E. F., \& Jensen, M. C. (1983). Separation of ownership and control. Journal of Law and Economics, 26(2), 301-325.

Fazzari, S. M., Hubbard, R. G., \& Petersen, B. C. (1988). Financing constraints and corporate investment. NBER Working Papers, 2387, National Bureau of Economic Research.

Freel, M. S. 2007. Are small innovators credit rationed? Small Business Economics, 28: 23-35.

Fungacova, Z., Shamshur, A., \& Weill, L. (2017). Does bank competition reduce cost of credit? Cross-country evidence from Europe. Journal of Banking and Finance, 83, 104-220.

Godlewski, C. J., \& Weill, L. (2011). Does collateral help mitigate adverse selection? A crosscountry analysis. Journal of Financial Services Research, 40, 49-78. DOI 10.1007/s10693-010-0099-y

Grunert, J., \& Norden, L. (2012). Bargaining power and information in SME lending, Small Business Economics, 39, 401-417. DOI 10.1007/s11187-010-9311-6

Hainz, C., Weill, L., \& Godlewski, C. J. (2013). Bank competition and collateral: Theory and evidence. Journal of Financial Services Research, 44, 131-148. DOI 10.1007/s10693-0120141-3

Hauswald, R., \& Marquez, R. (2006). Competition and strategic information acquisition in credit markets. Review of Financial Studies, 19(3), 967-1000.

Hsiao, Y. Z., \& Chou, N. T. (2015). Owner characteristics and the cost of Bank loan: Evidence from Small Business, http://papers.ssrn.com/sol3/papers.cfm?abstract_id=2562981

Jensen, M., \& Meckling, W. (1976). Theory of the firm, managerial behaviour, agency costs and ownership structure. Journal of Financial Economics 5, 305-306.

Jimenez, G.; Salas, V., \& Saurina, J. (2006). Determinants of collateral, Journal of Financial Economics 81: 255-281. http://dx.doi.org/10.1016/j.jfineco.2005.06.003

Lee, N., Sameen, H., \& Cowling, M. (2015). Access to finance for innovative SMEs since the financial crisis, Research Policy 44: 370-380. http://dx.doi.org/10.1016/j.respol.2014.09.008 
Leon, F. (2015). Does bank competition alleviate credit constraints in developing countries? Journal of Banking and Finance, 57, 130-142.

Love, I., \& Peria M. S. (2015). How bank competition affects firms access to finance. World Bank Economic Review, 29(3), 413-448.

Malafronte, I., Monferra, S., Porzio, C., \& Sampagnaro, G. (2014). Competition, specialization, and bank-firm interaction: What happens in credit crunch periods. Applied Financial Economics, 24(8), 557-571.

Marquez, R. (2002). Competition, adverse selection, and information dispersion in the banking industry. Review of Financial Studies, 15(3), 901.

Moro, A., Fink, M., \& Maresch, D. (2015). Reduction in information asymmetry and credit access for small and medium sized enterprises. The Journal of Financial Research, Vol. XXXVIII (1), 121-143.

Neuberger, D., \& Rathke-Doppner, S. 2015. The role of demographics in small business loan pricing, Small Business Economics, 44: 411-424.

Nguyen, S., \& Wolfee, S. (2016). Determinants of successful access to bank loans by Vietnamese SMEs: new evidence from the red river delta. Journal of Internet Banking and Commerce, 21(1), 1-23.

Panzar, J., \& Rosse, J. (1987). Testing for monopoly equilibrium. The Journal of Industrial Economics, XXXV(4), 443-453.

Petersen, M.A. \& Rajan, R.G. (1995). The effect of competition on lending relationship. The Quarterly Journal of Economics, 110(2), 407-443.

Rahman, A., Belas, J., Kliestik, T., \& Tyll, L. (2017). Collateral requirements for SME loans: empirical evidence from the Visegrad countries. Journal of Business Economics and Management, 18(4), 650-675.

Rahman, A., Rozsa, Z., Kozubikova, L., \& Cepel, M. (2017). Determinants of loan maturity in small business lending. Journal of International Studies, 10(2), 104-118.

Ryan, R.M., O'Toole, C.M., \& McCann, F. (2014). Does bank market power affect SME financing constraints? Journal of Banking and Finance, 49, 495-505. 